\title{
FAKTOR YANG MEMPENGARUHI PENGAMBILAN KEPUTUSAN DALAM PENGGUNAAN LAYANAN KESEHATAN PADA WILAYAH KERJA PUSKESMAS TAWIRI
}

\author{
Arwyn W. Nusawakan ${ }^{1 *}$, Sanfia Tesabela Messakh ${ }^{2}$, Sevnat Jambormias ${ }^{3}$ \\ ${ }_{* 1,2,3}$ Fakultas Kedokteran dan IImu Kesehatan, Universitas Kristen Satya Wacana, Jl. Kartini No.11A \\ Salatiga 50711, e-mail: arwyn.nusawakan@staff.uksw.edu
}

\begin{abstract}
Background: Health is one of the important aspects in human life that will be maintained. The effort to maintain includes the right of decision-making to use health services provided in the community. Data on access to health services and facilities shows low number of visits to these facilities and it arises the question of the reason behind the low number of access.

Objective: The purpose is to identify factors affecting the decision-making in the use of health services by the community of Hative Besar Village, Ambon-Maluku.

Method: The approach used in this study is qualitative descriptive. Data is collected through semi-structured, in-depth interview. 8 natives of Hative Besar Village, Ambon-Maluku are involved as research participants.

Result: Decision making in the use of health services by the community influenced by health-illness perception, professional services and the experience of using health care services are major factors that influence the Hative Besar village perception and later cause the emergence of factors decision in family and the cost.

Conclusion: Factors that influence the decision-making by the community of Hative Besar Village in the use of health care facilities are health-illness perception, the experience of using health care services, professional services, decision in family and the cost.
\end{abstract}

Keywords: health, decision, community, health care

\section{PENDAHULUAN}

Kesehatan merupakan salah satu aspek yang terpenting dalam kehidupan manusia. Setiap orang akan berusaha untuk mempertahankan derajat kesehatannya. Salah satu upaya untuk mempertahankan derajat kesehatan tersebut adalah dengan cara menggunakan layanan kesehatan yang disediakan oleh pemerintah maupun swasta. Pemerintah maupun swasta telah menyediakan beberapa layanan kesehatan yang besifat bangunan fisik untuk masyarakat seperti rumah sakit, puskesmas, panti jompo, dan layanan kesehatan. Selain itu, terdapat program-program layanan kesehatan, salah satu program yang diselenggarakan oleh Pemerintah Indonesia adalah program Jaminan Kesehatan Nasional (JKN) yang secara operasional dilakukan oleh Badan Penyelenggara Jaminan Sosial (BPJS). ${ }^{1,2,3}$

Akhir Desember 2015, tercatat jumlah masyarakat Indonesia yang telah menjadi peserta program JKN sebesar 70,51\% yaitu berjumlah 156.790.287 jiwa. Jumlah tersebut meningkat dibandingkan tahun 2014 sebesar $17,51 \%$ yaitu dari 133.423 .653 jiwa. $^{2}$ Hal ini menunjukkan bahwa masyarakat dari tahun ke tahun ingin menjadi peserta jaminan kesehatan dan mendapat perlindungan kesehatan serta kesejahteraan dari program tersebut.

Meskipun peserta program JKN dari tahun ke tahun mengalami peningkatan, 
namun disisi lain peningkatan keikutsertaan dalam jaminan kesehatan belum tentu mempengaruhi kunjungan ke layanan kesehatan. Beberapa hasil penelitian menunjukkan bahwa masyarakat yang memiliki JKN tidak sepenuhnya memanfaatkan layanan kesehatan dikarenakan fasilitas, ketersediaan obat yang terbatas serta mutu layanan yang diberikan oleh para tenaga kesehatan masih kurang, dan terkait juga dengan ekonomi dari masyarakat itu sendiri. ${ }^{1,12}$

Penggunaan layanan kesehatan di Maluku juga termasuk kategori cukup rendah. Hal ini dapat dilihat dari beberapa data terkait kunjungan pada layanan kesehatan yang menyatakan bahwa : angka kunjungan ibu hamil di tahun 2015 sebesar $43.88 \%$ dari 43.050 ibu hamil; kunjungan ibu nifas di 2015 sebesar $43.39 \%$ dari 41.480 ibu nifas; kunjungan neonatal lengkap tahun 2015 sebesar $42.60 \%$ dari 43.699 kelahiran yang hidup. $^{2}$ Beberapa contoh tersebut menunjukkan bahwa hanya sepersekian persen yang mengunjungi layanan kesehatan untuk mendapatkan layanan kesehatan.

Selain dilihat dari angka kunjungan, terdapat angka penyakit dalam kategori 10 penyakit dan meningkat di setiap tahunnya yaitu dari tahun 2012 sampai 2014 di Maluku. ${ }^{18}$

Berdasarkan data sepuluh penyakit terbesar di provinsi maluku tahun 2012 - 2014 di Maluku (Tabel 1), dapat dilihat perbandingan dari tiga tahun terdapat peningkatan terjadinya kasus penyakit di antaranya penyakit Infeksi Saluran Pernafasan Atas (ISPA), reumatik, dan diare.

\section{Tabel 1. Beberapa Penyakit Terbesar di}

Provinsi Maluku Tahun 2012 - 2014

\begin{tabular}{|c|c|c|c|c|c|}
\hline $\begin{array}{c}\text { Kasus } \\
2012\end{array}$ & $\begin{array}{c}\text { Juml } \\
\text { ah }\end{array}$ & $\begin{array}{c}\text { Kasus } \\
2013\end{array}$ & $\begin{array}{c}\text { Juml } \\
\text { ah }\end{array}$ & $\begin{array}{c}\text { Kasus } \\
2014\end{array}$ & $\begin{array}{c}\text { Juml } \\
\text { ah }\end{array}$ \\
\hline ISPA & 15.44 & ISPA & 21.54 & ISPA & 145.8 \\
\hline Reumatik & 8.549 & Reumatik & 12.76 & Reumatik & 28.28 \\
\hline $\begin{array}{l}\text { Diare } \\
\text { Penyakit }\end{array}$ & 3.094 & $\begin{array}{l}\text { Diare } \\
\text { Peyakit }\end{array}$ & 4.371 & $\begin{array}{l}\text { Diare } \\
\text { Penyakit }\end{array}$ & 14.84 \\
\hline $\begin{array}{l}\text { kulit } \\
\text { infeksi } \\
\text { Penyakit }\end{array}$ & 1.587 & $\begin{array}{l}\text { kulit } \\
\text { alergi } \\
\text { Penyakit }\end{array}$ & 2.480 & $\begin{array}{l}\text { kulit } \\
\text { alergi }\end{array}$ & 13.54 \\
\hline $\begin{array}{l}\text { Kardiova } \\
\text { skuler }\end{array}$ & 1.525 & $\begin{array}{l}\text { kardiovas } \\
\text { kuler }\end{array}$ & 2.835 & Hipertensi & 13.47 \\
\hline
\end{tabular}

Melihat data terkait rendahnya akses layanan dan fasilitas kesehatan dan kaitannya dengan peningkatan kejadian kasus penyakit, maka timbul pertanyaan tentang apa yang menyebabkan hal ini terjadi. Upaya untuk mempertahankan kesehatan memerlukan adanya pengambilan keputusan yang tepat dalam memanfaatkan layanan kesehatan. Pengambilan keputusan merupakan hasil dari sebuah pemikiran kritis yang ditujukan untuk menyelesaikan atau memecahkan sesuatu. ${ }^{5}$

Hasil beberapa studi terkait rendahnya akses layanan kesehatan, menemukan bahwa beberapa faktor dapat memengaruhi pengambilan keputusan dalam penggunaan layanan kesehatan yang terjadi di dalam masyarakat. Studi didapatkan bahwa kualitas pelayanan, citra rumah sakit dan citra tenaga kesehatan dapat memengaruhi pengambilan keputusan dalam pemanfaatan layanan kesehatan; adanya peranan keluarga; pendapatan, persepsi terhadap jarak ke fasilitas layanan 
kesehatan, sarana-prasana layanan kesehatan, persepsi biaya layanan kesehatan serta tersedianya sarana dan fasilitas layanan kesehatan dapat memengaruhi pengambilan keputusan dalam penggunaan layanan kesehatan. 5,6,7,8,9,10

Ada hal-hal tertentu yang menjadi pertimbangan atau melatarbelakangi pengambilan keputusan dalam penggunaan layanan kesehatan. Menurut Sarwono, keputusan untuk mencari suatu layanan kesehatan dipengaruhi tiga komponen yaitu predisposisi, pendukung (enabling), dan kebutuhan (need).

Komponen predisposisi yang terdiri dari faktor demografi (usia, jenis kelamin, status perkawinan dan jumlah anggota keluarga), faktor struktur sosial (jenis pekerjaan, status sosial, keyakinan, pendidikan, ras dan suku), dan faktor budaya. Hasil beberapa studi menunjukkan bahwa tingkat pendidikan dan pengalaman dalam menggunakan layanan kesehatan seseorang dalam masyarakat akan berdampak pada pengetahuan seseorang dan pengetahuan tersebut yang akan memengaruhi untuk pengambilan keputusan dalam penggunaan layanan kesehatan. 8,10,11

Komponen pendukung (enabling) merupakan faktor sumber daya dalam keluarga (penghasilan keluarga, kemampuan memilih dan menggunakan jasa pelayanan serta keikutsertaan dalam asuransi kesehatan) dan faktor sumber daya dalam masyarakat (jumlah sarana pelayanan kesehatan, jumlah tenaga kesehatan, rasio penduduk dan tenaga kesehatan, lokasi sarana kesehatan). Hasil beberapa studi merujuk ke faktor sumber daya dalam keluarga menunjukkan bahwa pendapatan keluarga dapat memengaruhi pengambilan keputusan dalam penggunaan layanan kesehatan. $5,8,10,12,13$ Merujuk ke faktor sumber daya dalam masyarakat, beberapa studi menunjukkan bahwa ketersediaan fasilitas dan sarana prasarana untuk menunjang pelayanan kesehatan dapat memengaruhi pengambilan keputusan dalam penggunaan layanan kesehatan. ${ }^{8,9,10,14}$ Selain itu, sikap yang ditunjukan oleh tenaga kesehatan yang dalam hal ini memberikan pelayanan kesehatan dapat memengaruhi pengambilan keputusan dalam penggunaan layanan kesehatan. ${ }^{1,6,7,8,9,10,11}$

Komponen kebutuhan (need) dilihat dengan adanya laporan tentang berbagai gejala penyakit dan jenis penyakit yang terjadi serta fungsi-fungsi tubuh yang terganggu. Hal ini memberikan pengaruh kepada masyarakat untuk dapat mencari alternatif pelayanan kesehatan. Hasil studi menunjukkan bahwa ketika angka kejadian suatu penyakit tinggi di suatu tempat, maka masyarakat akan sangat sensitif dengan gejala yang muncul sehingga ketika hal tersebut terjadi akan memengaruhi pengambilan keputusan dalam penggunaan layanan kesehatan. Akan tetapi keputusan yang diambil akan saling terkait antara kebutuhan dengan faktor lainnya. ${ }^{15}$ 
Beberapa hal yang telah disebutkan diatas menunjukkan terdapat berbagai faktor yang dapat melatarbelakangi pengambilan keputusan dalam penggunaan layanan kesehatan. Berdasarkan latar belakang tersebut, peneliti tertarik untuk meneliti faktorfaktor yang memengaruhi pengambilan keputusan dalam penggunaan layanan kesehatan di Desa Hative Besar pada wilayah kerja Puskesmas Tawiri.

Tujuan penelitian ini adalah untuk mengidentifikasi faktor-faktor yang memengaruhi pengambilan keputusan dalam penggunaan layanan kesehatan masyarakat desa Hative Besar, Kota Ambon, Provinsi Maluku.

\section{BAHAN DAN CARA PENELITIAN}

Penelitian ini menggunakan metode penelitian kualitatif-deskriptif. Pengumpulan data menggunakan teknik wawancara yang dilakukan secara mendalam dan semi terstruktur kepada partisipan dengan pedoman yang telah dibuat. ${ }^{16}$ Penentuan partisipan menggunakan teknik purposive sampling. Partisipan berjumlah 8 orang yang diambil berdasarkan kriteria seperti penduduk asli tinggal dan menetap di desa Hative Besar, sudah berkeluarga dan sedapatnya pernah menggunakan suatu layanan kesehatan. Semua data yang telah diperoleh dari partisipan kemudian dianalisis sesuai dengan prosedur penelitian kualitatif yaitu: mengurutkan data ke dalam pola, pengkategorian data sehingga dapat memunculkan tema, dan pentafsiran data berdasarkan tema yang muncul sehingga menghasilkan sebuah kesimpulan. ${ }^{17}$ Penelitian ini dilakukan pada wilayah kerja Puskesmas Tawiri di Desa Hative Besar Kota Ambon. Waktu penelitian dilaksanakan selama satu bulan yaitu Februari 2017.

\section{HASIL DAN PEMBAHASAN}

Berdasarkan hasil analisa data,
ditemukan lima tema yang dapat
memengaruhi masyarakat Desa Hative Besar untuk mengambil keputusan dalam penggunaan layanan kesehatan.

\section{Kesehatan Merupakan Sesuatu Yang Penting dan Harus Dijaga}

Partisipan memiliki persepsi bahwa sehat atau kesehatan itu penting dan harus dipertahankan. Seluruh partisipan mengungkapkan bahwa kesehatan itu penting untuk itu harus diutamakan dan dijaga seperti beberapa contoh kutipan wawancara kutipan berikut.

"...beta deng keluarga anggap kesehatan itu penting...deng harus jaga akang..." (Partisipan 4)

“...saya dan keluarga menggangap kesehatan itu penting... dan kesehatan harus dijaga..." (Partisipan 4)

Persepsi partisipan mengenai kesehatan itu sesuatu yang penting, utama, dan harus dijaga, membuat masyarakat mengambil langkah yang tepat ketika kondisi kesehatannya terganggu. Ketika dalam kondisi kesehatan terganggu masyarakat 
akan melakukan berbagai usaha untuk dapat mempertahankan kesehatannya seperti semula. Hal ini juga yang dapat memengaruhi mereka untuk mengambil keputusan dalam menggunakan layanan kesehatan.

Persepsi mengenai sehat penting bagi masyarakat dalam meningkatkan kepekaan mereka dalam menjaga dan mengusahakan diri agar tetap dalam kondisi sehat. Hal ini sejalan dengan hasil penelitian yang dilakukan di salah satu puskesmas di Poso, menyatakan bahwa ada hubungan antara persepsi sehat dengan pemanfaatan pelayanan kesehatan. Masyarakat yang mempersepsikan kesehatan itu penting, akan tanggap dan mencari pertolongan jika terjadi gangguan dan atau penyakit. Tindakan mencari pertolongan tersebut, maka masyarakat akan mengontak dan menggunakan layanan kesehatan yang diyakini mampu menangani gangguan dan atau penyakit yang dialami. ${ }^{12}$

Hasil yang sama juga ditunjukan oleh penelitian yang dilakukan di Puskesmas Marusu Kecamatan Marusu. Hasil penelitian tersebut menyatakan bahwa ada hubungan antara persepsi dengan pemanfaatan pelayanan kesehatan. Persepsi sehat satu orang dengan yang lain berbeda karena setiap orang memiliki cara pandang masingmasing. Salah satunya mengenai bagaimana cara mengupayakan kesehatan dan mencari pertolongan untuk mempertahankan maupun mengembalikan status sehat pada dirinya. ${ }^{7}$

\section{Memilih untuk Mendapatkan Layanan Kesehatan Profesional}

Persepsi partisipan mengenai kesehatan merupakan sesuatu yang penting, mendorong masyarakat untuk mencari pertolongan dengan mendapatkan layanan kesehatan profesional pada saat kesehatannya terganggu. Partisipan lebih mempercayakan layanan kesehatan profesional dikarenakan layanan kesehatan yang profesional memberikan layanan yang pasti yang dimana sudah berpengalaman dalam memberikan perawatan mendatangkan kesembuhan.

Ketika kondisi sehatnya terganggu, masyarakat desa Hative Besar akan memilih untuk mendapatkan layanan kesehatan dari layanan kesehatan profesional dari pada praktik kesehatan tradisional. Walaupun dalam kunjungannya sebagian masyarakat akan memilih untuk mengunjungi dokter praktik di klinik di desa Wayame dan sebagian masyarakat yang lainnya akan memilih untuk mengunjungi Puskesmas Tawiri seperti kutipan wawancara berikut :

“... iyo, kalau rasa diri su saki bagitu, langsung bawa lari ka Pukesmas Tawiri saja ... katong cari yang pasti to " (Partisipan 8)

“... iya, kalau merasa tubuh sakit, kemudian langsung dibawa saja ke Puskesmas Tawiri ... Kami cari yang pasti saja" (Partisipan 8)

Pelayanan kesehatan yang pasti merupakan pelayanan yang banyak dicari oleh masyarakat. Hal ini ditunjang dengan hasil penelitian yang dilakukan di puskesmas pembantu di Kutai Barat yang menunjukkan 
bahwa layanan kesehatan profesional banyak dicari oleh masyarakat untuk mendapatkan pelayanan kesehatan. Masyarakat mencari pelayanan kesehatan profesional dikarenakan layanan kesehatan tersebut diseleggarakan sesuai dengan aturan standar operasional prosedur kesehatan. ${ }^{19}$

Serupa dengan hasil penelitian yang dilakukan di rumah sakit mengenai hak paten untuk memperoleh pelayanan, menunjukkan bahwa masyarakat akan mencari dan menggunakan suatu layanan kesehatan profesional dikarenakan ingin mendapatkan kualitas pemeriksaan dan pengobatan yang baik. Keinginan masyarakat tersebut dapat terpenuhi dengan menggunjungi layanan kesehatan yang sudah profesional seperti puskesmas dan klinik. ${ }^{20}$

\section{Pengalaman Penggunaan Layanan Kesehatan}

Layanan kesehatan yang hendak dikunjungi oleh partisipan untuk mendapatkan layanan kesehatan profesional akan bergantung pada faktor pengalaman. Faktor tesebut sebenarnya memiliki keterkaitan dengan faktor sebelumnya yang di mana hal tersebut dapat memengaruhi keputusan dalam penggunaan layanan kesehatan.

Pengalaman penggunaan layanan kesehatan oleh masyarakat desa Hative Besar dibentuk oleh dua faktor antara lain faktor kecocokan dengan pengobatan dan faktor kebiasaan menggunakan suatu layanan kesehatan. Pengalaman yang dimaksudkan adalah pengalaman setiap keluarga dalam masyarakat Hative Besar dalam menggunakan layanan kesehatan. Pengalaman tersebut mengarahkan pilihan masyarakat terkait cocok tidaknya perawatan atau pengobatan yang didapatkan. Selain itu kebiasaan adalah kebiasaan keluarga yang sebelumnya menggunakan suatu layanan kesehatan juga membuat mereka lebih memilih tempat layanan kesehatan tersebut.

“...beta dari sewaktu ana-ana lai orang tua sudah biasa kalau saki bawa ka dokter praktek. Jadi pas di beta keluarga langsung sa bawa ka dokter praktek..." (Partisipan 3)

“...saya dari sewaktu kanak-kanak, orang tua sudah biasa kalau sakit dibawa ke klinik dokter. Jadi ketika di keluarga saya langsung saja bawa ke klinik dokter..." (Partisipan 3)

Pengalaman penggunaan layanan kesehatan yang pertama yaitu kecocokan dengan pengobatan adalah pengalaman masyarakat atau keluarga sendiri mengenai kecocokan dengan obat yang diprogramkan oleh dokter. Masyarakat desa Hative Besar jika sudah merasa cocok dengan pengobatan berupa obat yang diberikan atau diprogramkan akan dengan seterusnya memilih mengunjungi layanan kesehatan tersebut. Sebaliknya jika masyarakat tidak merasa cocok dalam artian tidak memperoleh kesembuhan, maka masyarakat tidak akan mengunjungi layanan kesehatan tersebut dalam beberapa waktu kedepan.

Pengalaman penggunaan layanan kesehatan yang kedua yaitu kebiasaan 
keluarga menggunakan suatu layanan kesehatan adalah pengalaman masyarakat atau keluarga sendiri secara turun-temurun dari sebelumnya telah menggunakan suatu layanan kesehatan tertentu. Masyarakat desa Hative Besar terkhususnya keluarga yang sudah terbiasa menggunakan suatu layanan kesehatan secara turun temurun, maka keluarga tersebut akan mempercayai layanan kesehatan tersebut untuk mengusahakan kesehatannya.

Kecocokan dengan pengobatan yang didapatkan dan kebiasaaan menggunakan suatu layanan kesehatan merupakan bentuk dari pengalaman yang dialami oleh masyarakat. Hasil penelitian ini sesuai dengan penelitian di RSUD Panembahan Senopati Bantul yang menunjukkan bahwa pengalaman pasien terhadap suatu layanan kesehatan akan bergantung pada beberapa aspek yaitu kepuasan terhadap informasi, kepuasan terhadap staff dan kepercayaan pasien terhadap petugas kesehatannya. ${ }^{21}$

Studi lain yang hasilnya serupa dilakukan di RSUD Majene, yang menunjukkan bahwa kebiasaan menggunakan layanan kesehatan dikarenakan layanan kesehatan tersebut memberikan jasa (pelayanan kesehatan yang sesuai). Jasa yang diberikan suatu layanan kesehatan dan diterima oleh masyarakat, jika sesuai dengan yang diharapkan maka akan dipergunakan kembali terus menerus. ${ }^{22}$
Proses Pengambilan Keputusan dalam Bentuk Musyawarah Keluarga

Selain beberapa tema yang dikemukakan di atas, tema lain muncul terkait penggunaan layanan kesehatan oleh partisipan yaitu tentang proses pengambilan keputusan dalam keluarga. Proses ini berupa musyawarah keluarga yang dilakukan sehingga keputusan dalam penggunaan layanan kesehatan yang sesuai dapat diambil dengan mufakat bersama seperti kutipan wawancara dengan responden berikut ini :

“...perihal saki nih katong bicarakan lai par suami deng anak... deng biasanya suami yang ambe keputusan... (Responden 7)

“...masalah sakit ini, saya bicarakan juga bersama suami dan anak...dan biasanya suami yang mengambil keputusan..." (Responden 7)

Pengambilan keputusan dalam hal ini dipandang oleh masyarakat desa Hative Besar merupakan sesuatu yang tidak dapat dilakukan sendiri dan memerlukan bantuan dari orang lain. Biasanya yang lebih dominan dalam pengambilan keputusan di keluarga adalah orang yang lebih mengetahui kondisi gangguan kesehatan atau penyakit yang dialami. Pengambil keputusan dalam keluarga harus cepat dan tepat, hal tersebut yang lebih dominan dilakukan oleh suami atau kepala keluarga dari pada ibu atau istri.

Adanya suatu proses pengambilan keputusan dalam keluarga jika menghadapi sebuah situasi yang mengharuskan untuk dilakukan pengambilan keputusan. Hal tersebut harus dibicarakan bersama mengingat pengalaman penggunaan suatu 
layanan kesehatan berbeda satu anggota keluarga dengan yang lain.

Hal ini sejalan dengan hasil penelitian yang dilakukan di Rumah Sakit Umum Daerah Sumedang, menunjukkan bahwa adanya pengambilan keputusan dalam keluarga ditempuh melalui musyawarah keluarga. Musyawarah yang dilakukan yaitu antara suami dan istri dan/atau bersama seluruh anggota keluarga. Biasanya yang lebih dominan mengambil keputusan yang cepat adalah suami. ${ }^{23}$

Hasil penelitian tersebut didukung oleh penelitian yang dilakukan di Riau, menunjukkan bahwa kepala keluarga yaitu ayah/suami akan lebih dominan mengambil keputusan dalam keluarga. Hal tersebut dipengaruhi beberapa faktor di antaranya pengetahuan, sikap dan perilaku. ${ }^{24}$

\section{Tingkat Pendapatan Keluarga}

Tema terakhir yang muncul adalah terkait persoalan keuangan. Keuangan yang dimaksudkan adalah tingkat pendapatan masyarakat per keluarga yang cenderung berbeda. Perbedaan ini juga yang membuat masyarakat memiliki cara pandang berbeda dalam mengambil sebuah keputusan dalam penggunaan layanan kesehatan.

Jika Upah Minimum Kota (UMK) Kota Ambon untuk tahun 2017 adalah sebesar Rp. 2,100,000, maka masyarakat desa Hative Besar yang memiliki pendapatan perkeluarga di bawah UMK akan lebih cenderung mengambil keputusan untuk mengusahakan kesehatannya dengan mengunjungi layanan kesehatan profesional yang disediakan pemerintah di desa terdekat seperti Puskesmas Tawiri. Alasan yang dikemukakan masyarakat mengenai hal ini adalah mendapat pengobatan di Puskesmas tidak mengeluarkan banyak biaya, paling hanya beberapa ribu rupiah dapat pengobatan dan sembuh.

“...katong pendapatan keluarga seng banya, paling sabulan Rp.900,000......deng kalau saki ka puskesmas Tawiri saja, katong lia uang lai toh......paling kaluar tiga ribu nai oto ka puskesmas, dua ribu ka tiga ribu bayar obat puskesmas la pulang minong obat teratur..." (Partisipan 8)

“...pendapatan keluarga kami tidak begitu banyak, paling penghasilan sebulan Rp.900,000......dan kalau sakit ke puskesmas Tawiri saja, kami lihat uang lagi kan......palingan hanya mengeluarkan Rp.3000,- untuk naik angkot ke Puskesmas Tawiri, Rp.2000/Rp.3000 untuk bayar obat puskesmas kemudian pulang ke rumah dan minum obat teratur..." (Partisipan 8)

Partisipan dengan tingkat pendapatan perkeluarga diatas UMK akan lebih memilih untuk menggunakan layanan kesehatan dokter praktik mandiri yaitu Klinik di Wayame. Dengan pendapatan perkeluarga diatas UMK tersebut, keputusan yang dimbil masyarakat untuk menggunakan layanan kesehatan profesional akan berpengaruh untuk mengunjungi klinik di Wayame. Mengingat jarak antara desa Hative Besar dan desa Wayame hanya menempuh sekitar kira-kira 500-900 meter dibandingkan dengan jarak antara desa Hative Besar dengan Desa 
Tawiri tmpat puskesmas bisa menempuh kira-kira 2-3 km. Masyarakat dengan tingkat pedapatan diatas UMK akan berpikir lagi untuk lebih baik jarak yang terdekat untuk mendapatkan layanan kesehatan profesional, tidak apa mengeluarkan banyak uang yang penting kesehatan bisa diusahakan.

Tingkat pendapatan keluarga akan menetukan bagaimana keluarga tersebut memenuhi kebutuhan hidup, sama halnya juga akan memengaruhi pemenuhan kebutuhan kesehatan. Hal ini sesuai dengan hasil penelitian yang dilakukan di Rumah Sakit PKU Muhammadiyah Kabupaten Boyolali yang menyatakan bahwa faktor biaya memengaruhi masyarakat untuk menggunakan suatu layanan kesehatan. Masyarakat dengan tingkat pendapatan rendah akan mengggunakan layanan kesehatan yang sesuai dengan pendapatannya. Lain hal dengan masyarakat dengan tingkat pendapatan tinggi akan mengeluarkan biaya seberapa pun untuk layanan terbaik dari suatu layanan kesehatan. $^{5}$

Hasil penelitian tersebut didukung oleh hasil penelitian yang dilakukan di Kecamatan Pamiinggir, menunjukkan bahwa faktor biaya memegang peran dalam masyarakat menggunakan suatu layanan kesehatan. Akan tetapi bergantung lagi pada permintaan kebutuhan akan obat ataupun pendapat tenaga kesehatan. Hal tersebut akan memungkinkan masyarakat dari kalangan manapun akan berusaha sebaik mungkin untuk mengembalikan kesehatannya seperti semula. ${ }^{8}$

\section{KESIMPULAN}

Berdasarkan hasil penelitian ini dapat disimpulkan bahwa pengambilan keputusan dalam penggunaan layanan kesehatan oleh masyarakat desa Hative besar dipengaruhi oleh persepsi sehat-sakit, layanan profesional dan pengalaman menggunakan layanan kesehatan yang selanjutnya menimbulkan munculnya keputusan dalam keluarga dan biaya.

\section{KEPUSTAKAAN}

1. Rumengan DSS, Umboh JML, Kandou GD. Faktor-Faktor yang Berhubungan dengan Pemanfaatan Pelayanan Kesehatan Pada Peserta BPJS Kesehatan di Puskesmas Paniki Bawah Kecamatan Mapanget Kota Manado. Jikmu. 2015;5:88-100.

2. Kementerian Kesehatan RI. Profil Kesehatan Indonesia Tahun 2015. Jakarta; 2016

3. Menkes RI. Peraturan Menteri Kesehatan RI Nomor 28 Tahun 2014 tentang Pedoman Pelaksanaan Program Jaminan Kesehatan Nasional. Jakarta; 2014

4. Badan Penyelenggara Jaminan Kesehatan. Laporan Manajemen Desember 2014 sampai dengan Agustus 2015. Jakarta; 2015

5. Anggraheni N. Faktor-faktor yang Memengaruhi Pengambilan Keputusan Masyarakat untuk Memilih Jasa Pelayanan Kesehatan di Rumah Sakit PKU Muhammadiyah Simo Kabupaten Boyolali. Universitas Muhammadiyah Surakarta; 2012.

6. Supariani NND. Faktor-faktor yang Berhubungan dengan Pemanfaatan Pelayanan Kesehatan Gigi dan Mulut di Poliklinik Gigi RSUD Kabupaten Badung. Skala Husada. 2011;10:20-4. 
7. Mujahidah, Darmawansyah, Amir $\mathrm{Y}$. Faktor yang Berhubungan dengan Perilaku Konsumen dalam Pemanfaatan Pelayanan Kesehatan di Puskesmas Masuru. 2013. 2013;1-14.

8. Marnah, Husaini, IImi B. Analisis Perilaku Masyarakat dalam Pemanfaatan Pelayanan Kesehatan Peserta Program Keluarga Harapan (PKH) di Kecamatan Paminggir. Jurnal Berkala Kesehatan. 2016;2:79-88.

9. Magan $\mathrm{H}$, Indra, Balqis. Faktor yang Berhubungan dengan Pemanfaatan Pelayanan Kesehatan Unit Rawat Jalan di Wilayah Puskesmas Makale. 2013;110.

10. Ridintika I, Rachmani E. Beberapa Faktor yang Berhubungan dengan Pemanfaatan Pelayanan Rawat Jalan oleh Masyarakat Di Wilayah Kerja Puskesmas Ungaran. VISIKES. 2009;8:54-63.

11. Lailatul UM, Herawati YT, Witcahyo E. Faktor yang Berhubungan dengan Pemanfaatan Pelayanan Antenatal oleh Ibu Hamil di Wilayah Kerja Puskesmas Tempurejo Kabupaten Jember Tahun 2013. Jurnal Pustaka Kesehatan. 2014;2(1):58-65.

12. Napirah MR, Rahman A, Tony A. Faktorfaktor yang Berhubungan dengan Pemanfaatan Pelayanan Kesehatan di Wilayah Kerja Puskesmas Tambarana Kecamatan Poso. Jurnal Pengembangan Kota. 2016;4:29-39.

13. Sulistyorini A, Purwanta. Pemanfaatan Fasilitas Pelayanan Pemerintah dan Swasta di Kabupaten Sleman. Artikel Penelitian. Fakultas Kedokteran Universitas Gadjah Mada; 2010

14. Alfiati $Y$, Marwati T, Solikha. Faktor-faktor yang Memengaruhi Pemanfaatan Pelayanan Poli Obsgyn di RSUD Banjarnegara. Jurnal Kesehatan Masyarakat. 2010;4:144-239.

15. Hussein RD, Musiana. Faktor-faktor yang Berhubungan dengan Pemanfaatan Puskesmas oleh Pasien Hipertensi. Jurnal Kesehatan. 2014;5:33-9.

16. Sugiyono. Memahami Penelitian Kualitatif. Bandung: CV. Alfabeta; 2012.
17. Moleong, J. Metodologi Penelitian Kuanlitatif. Bandung: PT Remaja Rosdakarya; 2014

18. Dinas Kesehatan Maluku. Profil Kesehatan Kota Ambon 2014. DINKES Kota Ambon; 2014.

19. Nurhayanti M. Peran Tenaga Medis dalam Pelayanan Kesehatan Masyarakat di Puskesmas Pembantu Linggang Amer Kec. Linggang Bigung Kab. Kutai Barat. Jurnal. 2016;4(1):2127-40.

20. Ginting G. Hak Paten untuk Memperoleh Pelayanan Kesehatan di Rumah Sakit di Tinjau dari Hak Asasi Manusia. 2014;2(2):70-80.

21. Cahyani IF, Kurniawati T. Hubungan Pengalaman Dirawat dengan Loyalitas Pasien Rawat Inap di Bangsal Penyait Dalam RSUD Panembahan Senopati Bantul. 2015;1-12.

22. Bauk I, Kadir R, Saleh A. Hubungan Karakteristik Pasien dengan Kualitas Pelayanan: Persepsi Pasien Pelayanan Rawat Inap RSUD Majene Tahun 2013. 2013;1-12.

23. Wulandari AP, Susanti AI, Mandiri A. Gambaran Pengambilan Keputusan Saat Proses Rujukan dari Tingkat Primer ke Tingkat Sekunder di RSUD Sumedang. JSK. 2015;2(2):56-62.

24. Desni F, Wibowo TA, Rosyidah. Hubungan Pengetahuan, Sikap, Perilaku, Kepala Keluarga dengan Pengambilan Keputusan Pengobatan Tradisional di Desa Rambah Tengah Hilir Kec.Rambah Kab.Rokan Hulu, Riau. Kesehatan Masyarakat. 2011;5(3):162-232. 